\title{
Interest and motivation of medical pediatric residents in the pedagogical process of teaching: preceptors' perception
}

\author{
Valmin Ramos-Silva \\ $\mathrm{PhD}$ in Pediatrics from (UFMG). Post-Doctor in Education from (UFES). Professor of Postgraduate Program in \\ Public Policies and Local Development at Escola Superior de Ciências da Santa Casa de Misericórdia de Vitória, \\ ES - EMESCAM \\ $\bowtie$ ana.pereira valmin.ramos@emescam.br \\ Janine Pereira da Silva \\ MSc. and PhD in Child and Adolescent Health (UFMG) Pediatrics. Professor of Postgraduate Program in Public \\ Policies and Local Development at Escola Superior de Ciências da Santa Casa de Misericórdia de Vitória, ES - \\ EMESCAM

\section{Loise Cristina Passos Drumond} \\ MSc. in Foreign Language Education from University of Tennessee System. Training in Clinical Psychoanalysis

\section{Catarina Bubach Ribeiro Alves} \\ Medical student at Escola Superior de Ciências da Santa Casa de Misericórdia de Vitória, ES - EMESCAM

\section{Hiran Pinel} \\ $\mathrm{PhD}$ in Psychology. Professor of the Graduate Program in Education. Federal University of Espirito Santo
}

\begin{abstract}
:
Although many say that the resident doctor has no interest in the activities developed during the medical residency in Pediatrics, this does not seem to be true, especially when it comes to secondary and tertiary care. The objective was to evaluate the preceptors' perception about Pediatric medical residents' interest and motivation in the teaching process. This is a cross-sectional study using a semistructured interview with preceptors in Pediatrics. This study included $40(67,8 \%)$ of 59 preceptors,

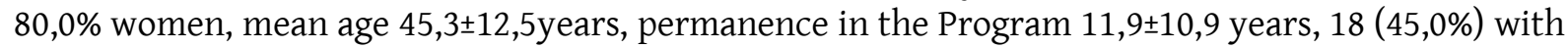
$\leq 5$ years as preceptor; $18(45,0 \%)$ reported no teacher training; 18 (45,0\%) deliver/discuss syllabus. Most stress-generating rotations were urgency/emergency, pediatric intensive care unit, hospital shifts and clinical case presentations. For $8(20.0 \%)$ preceptors, the resident physician presents a lower interest in attending the Program; 31 (77,5\%) greater interest in practical activities; $18(45,0 \%)$ reported interest and motivation for theoretical-practical contents. In those with time $\leq 5$ years, 6 $(33,3 \%)$ reported lack of enthusiasm; in the group > 5years, $2(9,1 \%)$ reported lack of enthusiasm $(p=0,057)$. For motivation, in both groups $\leq 5$ years $(16,7 \%)$ and $>5$ years $(13,6 \%), 3$ reported lower motivation $(p=0,789)$.In conclusion, receptors acknowledge that residency in medical education is important, but it is also stress-inducing. Accordingly, it is necessary to consider on the pursuit for modern teaching processes, allowing training, professional and personal growth, with prevention of organic and emotional dysfunctions, enhancing interest and motivation for the teaching process.

Keywords: Teaching, Preceptorship, Internship and Residency, Pediatrics.
\end{abstract}




\title{
Interesse e motivação dos médicos pediátricos residentes no processo pedagógico de ensino: a percepção dos preceptores
}

\begin{abstract}
Resumo:
Embora muitos digam que o médico residente não tem interesse nas atividades desenvolvidas durante a residência médica em Pediatria, tal não parece ser verdade, especialmente quando se trata de cuidados secundários e terciários. O objetivo foi avaliar a percepção dos preceptores sobre o interesse e a motivação dos médicos residentes em Pediatria no processo de ensino. Trata-se de um estudo transversal utilizando uma entrevista semiestruturada com os preceptores em Pediatria. Esse estudo incluiu 40 (67,8\%) de 59 preceptores, 80,0\% mulheres, idade média de 45,3 $\pm 12,5$ anos, permanência no Programa 11,9 $\pm 10,9$ anos, $18(45,0 \%)$ com $\leq 5$ anos como preceptor; $18(45,0 \%)$ reportaram não ter formação docente; $18(45,0 \%)$ entregam/discutem o programa. As rotações mais geradoras de stress foram de urgência/emergência, unidade de cuidados intensivos pediátricos, turnos hospitalares e apresentações de casos clínicos. Para 8 (20,0\%) preceptores, o médico residente tem menor interesse em cursar o Programa; 31 (77,5\%) maior interesse em atividades práticas; 18 (45,0\%) reportaram interesse e motivação para conteúdos teórico-práticos.Nos que têm tempo $\leq 5$ anos, $6(33,3 \%)$ reportaram falta de entusiasmo; no grupo $>5$ anos, $2(9,1 \%)$ reportaram falta de entusiasmo $(\mathrm{p}=0,057)$. Para motivação, em ambos os grupos $\leq 5$ anos $(16,7 \%)$ e $>5$ anos $(13,6 \%), 3$ reportaram menor motivação $(p=0,789)$. Em conclusão, os preceptores reconhecem que a residência no ensino médico é importante, mas é também indutora de stress. Assim, é necessário considerar a busca por processos de ensino modernos, permitindo a formação, o crescimento profissional e pessoal, com prevenção de disfunções orgânicas e emocionais, reforçando o interesse e a motivação para o processo de ensino.

Palavras-chave: Ensino, Preceptoria, Estágio e Residência, Pediatria.

\section{Interés y motivación de los residentes de medicina pediátrica em el proceso pedagógico de la enseñanza: la percepción de los preceptores}

\section{Resumen:}

Aun que muchos dicen que el médico residente no tiene interesse enlasactividadesdesarrolladas durante laresidencia médica enPediatría, esto no parece ser cierto, especialmente cuando se trata de atención secundaria y terciaria. El objetivo eraevaluarlapercepción de los preceptores sobre elinterés y lamotivación de los residentes de medicina pediátrica enelproceso de enseñanza. Este es unestudiotransversal mediante una entrevista semiestructuradaconlos preceptores de Pediatría. Este

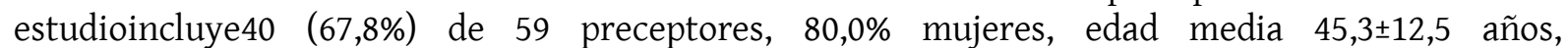
permanenciaenel Programa 11,9 $\pm 10,9$ años, $18(45,0 \%)$ con $\leq 5$ años como preceptor; $18(45,0 \%)$ reportaron no tenerformación docente; 18 (45,0\%) imparten/discutenel programa de estudiosLas rotaciones que generaronmayorestrésfueronurgencias/emergencias, unidad de cuidados intensivos pediátricos, turnos de hospital y presentaciones de casos clínicos. Para $8(20,0 \%)$ preceptores, el médico residente tiene menos interés en asistir al Programa; 31 (77,5\%) mayorinterésenactividadesprácticas; $18 \quad(45,0 \%)$ reportaroninterés y motivación por loscontenidosteórico-prácticosEnlos que tienentiempo $\leq 5$ años, 6 (33,3\%) reportaron falta de entusiasmo; enel grupo > 5 años, $2(9,1 \%)$ reportaron falta de entusiasmo $(\mathrm{p}=0,057)$. Encuanto a lamotivación, en ambos grupos s5years (16,7\%) y >5años (13,6\%), 3 informaron de una menor motivación $(\mathrm{p}=0,789)$. Enconclusión, los preceptores reconocen que laresidenciaenlaeducación médica es importante, pero tambiéninduce al estrés. Enconsecuencia, es necesario considerar enlabúsqueda de procesos de enseñanza modernos, que permitanlaformación, elcrecimientoprofesional y personal, conlaprevención de disfuncionesorgánicas y emocionales, aumentando elinterés y lamotivación por elproceso de enseñanza.

Palabras clave: Enseñanza, Preceptoría, Internado y residência, Pediatría. 


\section{INTRODUCTION}

One perceives motivation as an internal strength that surfaces, adjusts and maintains all the substantial human actions(SIMPSON; BALSAM, 2016). In this regard, it urges to recognize that resident physician as an individual provided with feelings and desires that seeks professional improvement to solve the most immediate health problems of other people(KARCHES; SULMASY, 2016). In such a way, one seeks to discuss issues experienced in the daily lives of preceptors and residents in Pediatrics, taking into account the resident physician as the target of the entire teaching-learning process developed in an environment of dissimilar complexity.

Besides, there are internal forces in motivation that have the power to sustain actions that generate human fulfillment needs and desires, joined with internal and external human biological behavior and condition, casted by experiences or biological and psychological mechanisms, and this motivation persists, thanks to these mechanisms(MICHELSON et al., 2019; DZENG; WACHTER, 2019; HENRY et al., 2018).

Preceptors and residents perceive that there is a lack of interest or motivation to carry out the activities defined during the Medical Residency period, but this has not been confirmed (RAMOS-SILVA et al., 2019). It is known that it is a difficult task to understand the factors that make up the teaching-learning process, as they represent challenges to perceive not only the internal organic forces, mainly the subjective ones, but also the external, immediate and broader ones, as institutional variables, political, media, economic, among others.

One may affirm that such forces can contribute or hinder human potentialities, either in the acquisition of skills (know-how) or in the theoretical field (knowledge), in the desire to obtain motivational resources to point out a world of possibilities in the identification of the elements that constitute interest and motivation, as well as learning processes among pediatric residents.

The preceptors of the multiprofessional healthcare program evaluated mistakenly believed that the motivation and interest of residents in pediatrics had lost strength over the years but, despite this, they persisted in demonstrating the ability to promote emancipatory teaching for resident physicians and build meanings with them for the daily experiences of 
dealing with patients, despite the working and teaching conditions offered (RAMOS-SILVA et al. 2019). Based on this, the study aims to evaluate the perception of preceptors about the interest and motivation of pediatric residents in the teaching process.

\section{METHOD}

This is an analytical cross-sectional study that aimed to assess preceptors of the Pediatric Medical Residency program of the Nossa Senhora da Glória State Children's Hospital (HEINSG), Vitória, ES, Brazil, from August to September 2015.

The HEINSG, created in 1933, is a public institution of direct state administration, exclusively bonded to the Unified Health System (SUS), that offers medium-sized tertiary care and is a state reference for high complexity for the urgency and emergency network; with about 5000 visits / month in outpatient clinics in the various specialties of Pediatrics, and approximately 350 hospitalizations / month, with a structure characterized by emergency care, pediatric and neonatal intensive care unit, clinical and surgical wards, operating room and burn treatment center. Each environment has the presence of resident physicians, with the participation of a multiprofessional healthcare team.

The Medical Residency Program (PRM) assessed was instituted in 1976 and prepared 594 pediatricians, by late of 2014, (508 / 85.5\% women). The PRM observes what is set by its Internal Regulations and this establishes rules for admission, appraisal for progression and course conclusion along with defining the Pedagogical Project (PP) annual review, as reported by the guidelines of National Medical Residency Commission (CNRM) to ensure : $a$ ) safe and effective care for each patient; b) development of skills, knowledge and attitudes; c) potential for future practice of continuous and unsupervised professional growth; d) definition of summative and formative evaluation criteria which supply the social insertion of the graduate, as a human resource of the Unified Health System. Moreover, the PP engages in matters of responsibility of the resident physician, as ethics, technical, scientific and social competence. The Program follows the workload percentages arranged by the CNRM, 
prioritizing greater workload, respectively, for teaching in primary, secondary and tertiary care.

An evaluation instrument containing open and closed questions, such as the profile of the preceptors, pedagogical demands, structure of the offered stages and the preceptors' view of the interest, motivation and stress generation in the offered stage was used for data collection.

Stress perception indicator, organized in Likert (1932) scale from 10.0 to $100.0 \%$ was applied in order to appraise the percentage of resident stress perceived by the preceptor during the internship. The study was approved by the HEINSG Research Ethics Committee, under Opinion No. 925,278.

The study variables were structured and assessed using SPSS for Windows software (Chicago, USA, version 25, series 10101141221). Categorical variables were displayed as absolute and relative frequencies, and quantitative variables were disclosed as mean and standard deviation or median and amplitude. For categorical variables, Pearson's chi-square test was implemented and a significance level of $5 \%(p<0.05)$ was adopted.

\section{RESULTS}

The program had 59 preceptors, however 11 (18.6\%) of them were not called to participate in the study for various reasons, such as vacations, maternity leave and premium vacations; 8 (13.5\%) rejected to participate; and $40(67.8 \%)$ responded to the evaluation instrument, 32 (80.0\%) female, mean age $45.3 \pm 12.5$ years and average time as preceptor in the program $11.9 \pm 10.9$ years.

Among preceptors under 40 (18 / 45.0\%) years of age, 16 (88.9\%) have worked for less than 5 years and 2 (11.1\%) have worked for more than 5 years. Notwithstanding, of the preceptors over 40 years old, only 2/22 (9.1\%) have been working for less than 5 years and 20/22 (90.9\%) have been working for over 20 years. Those who have been in the program for less than 5 years claimed not having done any training for teaching. The Table 1 presents the characterization of the preceptors. Table 1 presents the characterization of the preceptors. 
Table 1 -Characterization of the preceptors of the Pediatric Medical Residency program of Nossa Senhora da Glória State Children's Hospital (HEINSG), Vitória, ES, Brazil, $2015(\mathrm{n}=40)$

\section{VARIABLE}

FREQUENCY (PERCENTAGE)

\section{Gender}

$$
\text { Male }
$$

Female

$$
\begin{gathered}
\text { Age } \\
27-40 \\
41-50 \\
51-60 \\
61-73
\end{gathered}
$$

$$
8(20,0 \%)
$$$$
32(80,0 \%)
$$

$18(45,0 \%)$

$7(17,5 \%)$

$11(27,5 \%)$

$4(10,0 \%)$

\section{Program Acting Time (years)}
$1-5$
$18(45,0 \%)$
$6-10$
$4(10,0 \%)$
$11-15$
$5(12,5 \%)$
$16-20$
$3(7,5 \%)$
$21-35$
$10(25,0 \%)$

Source: elaborated by the authors.

As for the title, all preceptors had at least the Medical Residence in Pediatrics, as well as a master's degree (12.0\%) and a doctorate (8.0\%).

Regarding stress elicitation in the various stages that make up the curriculum matrix, the preceptors pointed the average of $50.5 \pm 25.8 \%$ (range 10.0 to $100.0 \%$ ) as stressors in physician residents. Yet, in the perception of preceptors, the stages identified as causing stress, between 10.0 and $30.0 \%$, refer to the presentation and discussion in clinicalradiological sessions, performance in some wards and outpatient clinics. The presentation and discussion in the pathological sessions, the activities on duty, and the stages developed 
in the emergency units, pediatric and neonatal intensive care, when compared to the other stages $(p<0.001)$ were indicated as stress greater than $50.0 \%$

In the pedagogical context, 18 (45.0\%) of the preceptors stated to deliver and discuss the teaching plan and the dynamics of the internship in its beginning; 11 (27.5\%) claimed not to submit the teaching plan but to discuss the internship dynamics with the resident physician at the beginning of the internship and 11 (27.5\%) said that this need does not apply to the coordinating internships. They also said that the evaluation process of the resident physician is performed at the beginning (13 / 32.5\%) and at the end of the internship (26 / $65.0 \%)$; applied in writing (15/37.5\%) or through group discussion (13 / 32.5\%), and with personal performance evaluation (24/60.0\%).

Preceptors who teach by way of scientific meetings, on-call activities and specialty outpatient clinics have subjective and non-systematized assessment models. In accordance with the scientific programming performed in each stage, 27 (67.5\%) declared that they accomplish planning; 29 (72.5\%) informed that the scheduled activity is fully fulfilled; and according to 30 (75.0\%) preceptors, residents articulate and contribute to the full realization of scientific programming. There is a consensus among 31 (77.5\%) preceptors that there is greater interest in practical activities and $18(45.0 \%)$ consider that there is interest in theoretical and practical content.

In assessing the resident physician's interest in chasing the internships offered by the program, 8 (20.0\%) preceptors stated that this one has been losing interest over the years and $6(15.0 \%)$ suppose that he is less motivated to study the stages. Among the preceptors who have worked in the program for less than 5 years, 33.3\% (6/18) pointed that the resident physician is less interested and motivated to attend the internships, but in the group with acting over 5 years this percentage is $9.1 \%(2 / 22)$.

\section{DISCUSSION}

It was noticed in this work that most preceptors are female, leading to interpret the influence of gender in the choice of pediatric specialty. Although the medical profession has 
been a male activity since its inception, pediatrics has historically been practiced by women. Studies evaluating this theme are scarce especially in pediatric residency programs

Wuillaume and Batista (2000) reported the work in the preceptorship in 30.0\%, with up to 10 years of activity, dissimilar to the data reported in this here where near half of the group (45.0\%) has up to 5 years of activity, all graduates of the program rated.

It is noted that almost half of the preceptors of the evaluated program are young people, what may suggest the retirement result of those who perform the function since the beginning of the program (1977), besides entering through public competitions. We highlight the high percentage of preceptors (37.5\%) over 50 years ( 51 to 73 years), which may represent the maximum of professional experience with positive repercussion in teaching processes. Botti and Rego (2011) point out that the shortage of preceptors under the age of 31 may suggest a relationship with the lack of public tender.

With regard to the title, $100.0 \%$ of the preceptors with specialization (Lato Sensu) in the area of Pediatric Medical Residency modality, and out of these $8.0 \%$ were PhD and $12.0 \%$ were masters. These results are inferior to those found by Botti and Rego (2011) who identified $50.0 \%$ of title in Stricto Sensu Program.

Regarding stress induced by various stages, including the medical working shifts, the Ministry of Education considers the Medical Residency the gold standard for specialization (CAMPOS, 2015). This has been combined with the best form of professional training for the doctor (OSLON et al., 2019), even though the constant pressure, physical tiredness, fatigue and fear of making mistakes. Apparently, this effect is greater among first-year resident physicians and among women (ASAIAG et al., 2010). All these situations, added to the constant demand of preceptors and patients, may be present during the Medical Residency period, growing professional responsibility and reducing time for social life, friends, family and leisure, which may affect the perception lived by the resident probably inducing disease processes(HU et al., 2019; MAGALHÃES; GLINA, 2006).

The view of the preceptors regarding the stress caused in the stages taught by themselves, brings a reflection on the seek for more modern teaching processes that can allow training, encourage professional and personal growth, hinder organ dysfunction and 
emotional turmoil in residents, increasing thus their motivation and their interest in the teaching-learning processes.

Consequently, it is desired that the preceptor has characteristics such as enthusiasm, compassion, open dialogue, conflict mediation, organization, involvement, integrity, knowledge and good relationship with patients, that is, positive attributes to be copied by residents who have the preceptor as an example. Moreover, professional and ethical behavior should be explicitly taught and encouraged, as unethical attitudes and behavior can cause confusion, distress and disappointment in supervised young physicians (PHILLIPS; DALGARNO, 2017; HATEM et al., 2011).

According to teacher's assumption, one notices the requirements of students such as clarifying doubts, proposing adequate, reflective and conscious feedback, promoting formative assessment, besides the summative, and using information technology. Burgess et al. (2014) claim that students selected as preceptor models those who have: 1) Clinical attributes: to attain a good knowledge base; articulate skills for conducting anamnesis; have aptitude to explain and demonstrate skills at the appropriate level for students; have empathy, respect and genuine compassion for patients. 2) Teaching skills: develop a relationship with students; provide time for students and professionals growth; supply a positive learning environment; understand student curriculum requirements and assessment; prompt and helpful feedback; and provide interaction with the patient. 3) Personal qualities: respectful inter-professional team interactions; tutorials preparation; passion for teaching; and passion for his career choice.

The study strengthens the main role of preceptors as models, which also has consequences for faculty growth in view of that almost half of the group is young, justifying the investment in the planning and continuous pedagogical upgrade of these preceptors. The medical education literature deliberates the different roles of the preceptor mentioning to as a mentor, tutor, supervisor and mentor, with functions of planning, controlling, guiding, stimulating reasoning and active posture, analyzing performance, advising and taking care of professional growth and personal, observing and evaluating the resident when performing his activities, besides acting in moral formation.

Hence, the rational teaching definitely entails reassessing the pedagogical practice and the expectations placed on the preceptor who, even with few teaching tools in the 
theoretical and pedagogical field, has the commitment to augment his field of action and his ability in order to build up quality education in accordance with the needs of the population, the citizenship advancement, the ethics and the competence to pledge with public opinion, with the errors, besides learning to face bad news and death.

Out of the current preceptors of the program evaluated, $45.0 \%$ have less than 5 years of experience and they have not undergone any kind of training for teaching, leading them to resent it. The lack of training was most likely due to the difficulty in recognizing the need to develop procedures inherent to teaching practice, such as internship planning, assessment and teaching procedures. Ourique (2010) argues that not determining, from the beginning, the point of arrival, is a learning to be further elaborated in the teacher training programs, implying a substantial difference in the way of understanding the formation, because the teaching lacks theoretical arguments to support them epistemological and public planes simultaneously, just as the material conditions of his work lack intervention devices.

There are preceptors who promote liberating teaching to their residents, building with them meanings for their daily experiences with patients, despite the working and teaching conditions provided by public sector.

With regard to practical and theoretical activities, practical learning can be analyzed from different angles and facets, but with a special focus on the role of the preceptor, a more experienced professional who assists in vocational training, but who needs not only understanding of his role in the training of the physician, but also his perception as a preceptor in this process of professional training(SKIPPER; MUSAEUS; NØHR, 2016; YARDLEY; TEUNISSEN; DORNAN, 2012).

This Medical Residency forms pediatricians able to work primarily at the hospital level, in inpatient units, urgency and emergency unit, pediatric intensive care units and neonatal, including low, medium and high complexity delivery room care. This training model is justified by the fact that there are difficulties in integrating the various levels of management in primary, secondary and tertiary care, considering that the internship fields were not designed to serve learners, thus making it difficult implementing strategies and strengthening health worker training (FRANÇA et al., 2017). 
According to Blank (2011), the main role of the preceptor of young resident doctors is to lead them to assimilate that this period of residence is just a warm-up of a life or course of life through systematic studies. The author also states that Medical Residency is the key period of medical education, where one improves the beginner's ability to continue selflearning as well as copes with future demands. Consequently, it is possible to unveil autonomy as one of the positive factors resulting from a meaningful, competent, committed, ethical, effective and engaging teaching-learning process. Autonomy requires a critical and practical reflection, from where the medical-pediatric theory aligns with clinical practice (FREIRE, 1996).

The option for pediatrics would be the essential element for residents' motivation, if it were not for the peculiar characteristics of the Medical Residency, with high potential to produce stress, often inducing frustrations with consequent reduction in motivation. In that regard, Pediatric Residency depends on the expertise of its preceptors to gather and value knowledge, based on the needs and expectations of students, planning authentic tasks with appropriate complexity, practice and useful task for professional practice that can broaden goals and encourage motivation(REED et al., 2018).

Teacher education in particular area of activity, related to psycho-pedagogical knowledge in the motivation area is a significant elementof motivational dynamics, in order to make the teaching-learning process more efficient. Thereby, it is crucial to contemplate on the perception and impact of the preceptor when defining, at the beginning of each stage, the motivated or unmotivated resident, considering his / her role in motivating the valorization of strategies of the theoretical-practical support of learning with quality (MAIESKI; OLIVEIRA; BZUNECK, 2013).

Learning motivation seems to be associated to positive results, effort and persistence in the search for knowledge and skills improvement, with intellectual growth. According to Chiavenato (1999), motivation is what drives the person to act in some sense, which may provoke an external stimulus, coming from the environment or internally generated in the mental processes of the individual. Thereby, the stress in the hospital learning environment is interpreted as absence of motivation, what demands the knowledge of how the student's behavior patterns are learned, and from these, deduce the existence of reasons, essences, driving force and intrinsic motivation(PAPAEFSTATHIOU et al., 2019). 
It is believed that man feels achieved when he encounters meaning in whatever he does. The human being is multidimensional and, therefore, it is essential to expand its operational, social and political dimensions, requiring the apprentice to provide space for creativity, autonomy and participation. Thus, it is suggested to group the factors concerned to motivation in the search for meaning, participation, education, communication and individual recognition (BUENO, 2002).

\section{CONCLUSION}

According to this research, the evaluated preceptors, mostly women under 40 years old, endorse that an overload among residents in the Medical Residency is present. This fact may ponder the search for modern teaching processes that can authorize training, promoting professional and personal growth, preventing organ dysfunction and emotional disturbance in residents. These preceptors also reiterate that the interest and motivation for the teaching-learning processes remain strong and unchanged.

As a limitation of the study, it is deemed that the evaluation considered merely a PRM of a state in the Southeast Region, nevertheless considering the dearth of national and international studies on the theme in the area of pediatric residency, the relevance of similar studies in the future is emphasized.

\section{REFERENCES}

ASAIAG, Paulo Eduardo; PEROTTA, Bruno; MARTINS, Milton de Arruda; TEMPSKI, Patrícia. Avaliação da qualidade de vida, sonolência diurna e burnout em Médicos Residentes. Revista Brasileira de Educação Médica, [s.1.], v. 34, n. 3, p. 422-429, set. 2010.

BLANK, Danilo. Residência Pediátrica: quantos seguidores teria hoje @william_osler?. Residência Pediátrica, [s.1.], v. 1, n. 2, p. 4-6, 2011.

BOTTI, Sérgio Henrique de Oliveira; REGO, Sérgio Tavares de Almeida. Docente-clínico: o complexo papel do preceptor na residência médica: o complexo papel do preceptor na residência médica. Physis: Revista de Saúde Coletiva, [s.l.], v. 21, n. 1, p. 65-85, 2011.

BUENO, Marcos. As teorias de motivação humana e sua contribuição para a empresa humanizada: um tributo a Abraham Maslow. Revista do Centro de Ensino Superior de Catalão - CESUC, [s.1.], v. 4, n. 6, 2002. 
BURGESS, Annette; OATES, Kim; GOULSTON, Kerry; MELLIS, Craig. First year clinical tutorials: students' learning experience. Advances in Medical Education and Practice, [s.l.], v. 5, n. 8, p. 451, nov. 2014.

CAMPOS, Vanessa Dalva Guimarães. Residência médica: desafios e perspectivas. Comunicação em Ciências da Saúde, [s.l.], v. 26, n. 3/4, p. 85-88, 2015.

CHIAVENATO, Idalberto. Gestão de pessoas: o novo papel dos recursos humanos nas organizações. Rio de Janeiro: Campus, 1999.

DZENG, Elizabeth; WACHTER, Robert M. Ethics in Conflict: Moral Distress as a Root Cause of Burnout. Journal of General Internal Medicine, [s.l.], v. 35, n. 2, p. 409-411, 2020.

FRANÇA, Tânia; MEDEIROS, Katia Rejane de; BELISARIO, Soraia Almeida; GARCIA, Ana Cláudia; PINTO, Isabela Cardoso de Matos; CASTRO, Janete Lima de; PIERANTONI, Célia Regina. Política de Educação Permanente em Saúde no Brasil: a contribuição das comissões permanentes de integração ensino-serviço. Ciência \& Saúde Coletiva, [s.l.], v. 22, n. 6, p. 1817-1828, jun. 2017.

FREIRE, Paulo. Pedagogia da autonomia. São Paulo: Paz e Terra, 1996.

HATEM, Charles J; SEARLE, Nancy S; GUNDERMAN, Richard; KRANE, N Kevin; PERKOWSKI, Linda; SCHUTZE, Gordon E; STEINERT, Yvonne. The Educational Attributes and Responsibilities of Effective Medical Educators. Academic Medicine, [s.1.], v. 86, n. 4, p. 474-480, abr. 2011.

HENRY, Duncan; VESEL, Travis; BOSCARDIN, Christy; SCHAIK, Sandrijn van. Motivation for feedback-seeking among pediatric residents: a mixed methods study. BMC Medical Education, [s.l.], v. 18, n. 1, p.145, 2018.

HU, Yue-Yung; ELLIS, Ryan J; HEWITT, D Brock; YANG, Anthony D; CHEUNG, Elaine Ooi; MOSKOWITZ, Judith T; POTTS III, John R; BUYSKE, Jo; Hoyt, David B; NASCA, Thomas J; BILIMORIA, Karl Y. Discrimination, Abuse, Harassment, and Burnout in Surgical Residency Training. The New England Journal of Medicine, [s.l.], v. 381, n. 18, p. 1741-1752, 2019.

KARCHES, Kyle E; SULMASY, Daniel P. Justice, Courage, and Truthfulness: Virtues That Medical Trainees Can and Must Learn. Family Medicine, [s.l.], v. 48, n. 7, p. 511-516, jul. 2016.

LIKERT, Rensis. A technique for the measurement of attitudes. Archives in Psychology, Nova Iorque, v. 140, p. 1-55, jun. 1932.

MAGALHÃES, Renato Arimateia Costa; GLINA, Débora Miriam Raab. Prevalência de Burnout em médicos de um Hospital Público de São Paulo. Saúde, Ética \& Justiça, [s.l.], v. 11, n. 1-2, p. 29, 7 nov. 2006.

MAIESKI, Sandra; OLIVEIRA, Katya Luciane de; BZUNECK, José Aloyseo. Motivação para aprender: o autorrelato de professores brasileiros e chilenos. Psico-USF, [s.1.], v. 18, n. 1, p. 53-64, abr. 2013.

MICHELSON, Catherine D; DZARA, Kristina; RAMANI, Subha; VINCI, Robert; SCHUMACHER, Daniel. Keystone: Exploring Pediatric Residents' Experiences in a Longitudinal Integrated Block. Teaching and Learning in Medicine, [s.l.], v. 31, n. 1, p. 99-108, 2019.

OSLON, Andrew; RENCIC, Joseph; COSBY, Karen; RUSZ, Diana; PAPA, Frank; CROSKERRY, Pat; ZIERLER, Brenda; HARKLESS, Gene; GIULIANO, Michael A; SCHOENBAUM, Stephen; COLFORD, Cristin; CAHILL, Maureen; GERSTNER, Laura; GRICE, Gloria R; GRABER, Mark L. Competencies for Improving Diagnosis: An Interprofessional Framework for Education and Training in Health Care. Diagnosis (Berl), [s.l.], v. 6, n. 4, p. 335$341,2019$.

OURIQUE, Maiane Liana Hatschbach. Performances da docência: compreensão das dimensões filosóficas da formação. Revista Brasileira de Educação, [s.l.], v. 15, n. 45, p. 544-554, dez. 2010. 
PAPAEFSTATHIOU, Efstathios; TSOUNIS, Andreas; PAPAEFSTATHIOU, Eirii; MALLIAROU, Maria; SERGENTANIS, Theodoros; SARAFIS, Pavlos. Impact of Hospital Educational Environment and Occupational Stress on Burnout Among Greek Medical Residents.BMC Research Notes, [s.l.], v. 12, n. 1, p. 281, 2019.

PHILLIPS, Susan P; DALGARNO, Nancy. Professionalism, Professionalization, Expertise and Compassion: A Qualitative Study of Medical Residents. BMC Medical Education, [s.l.], v. 17, n. 1, p.21, 2017.

REED, Suzanne; KEMPER, Kathi J; SCHWARTZ, Alan; BATRA, Maneesh; STAPLES, Betty B; SERWINT, Janet R; MCCLAFFERTY, Hilary; SCHUBERT, Charles J; WILSON, Paria M; RAKOWSKY, Alex; CHASE, Margaret; MAHAN, John D. Variability of Burnout and Stress Measures in Pediatric Residents: An Exploratory Single-Center Study From the Pediatric Resident Burnout-Resilience Study Consortium. JournalofEvidence-BasedIntegrative Medicine, [s.l.], v. 23, 2018.

SILVA-RAMOS, Valmin; SILVA, Janine Pereira; ALVES, Rosana S Cardoso; TRUGILHO, Silvia Moreira; COELHO, María C; DRUMOND, Loise Cristina Passos; COSTA, Solange Rodrigues da; SANTOS, Carla; PINEL, Hiran. Phenomenological Study about the Interest and Motivation of Physicians Residing in Pediatrics: Perception of the Preceptor.International Journal of Research Studies in Medical and Health Sciences, [s.l.], v. 4, n. 3, p. $11-16,2019$.

SIMPSON, Eleanor H; BALSAM, Peter D. The Behavioral Neuroscience of Motivation: An Overview of Concepts, Measures, and Translational Applications. Current Topics in Behavioral Neurosciences, [s.l.], v. 27, p. 1-12, 2016.

SKIPPER, Mads; MUSAEUS, Peter; NøHR, Susanne Backman. The paediatric change laboratory: optimising postgraduate learning in the outpatient clinic. BMC Medical Education, [s.l.], v. 16, p. 42, 2016.

WUILLAUME, Susana M; BATISTA, Nildo A. O preceptor na residência médica em Pediatria: principais atributos. Jornal de Pediatria, Rio de Janeiro, v. 76, n. 5, p. 333-338, 2000.

YARDLEY, Sarah; TEUNISSEN, Pim W; DORNAN, Tim. Experiential Learning: AMEE Guide No. 63. Medical Teacher, [s.l.], v. 34, n. 2, p. 102-115, 2012..

\section{(c)) $\mathrm{EY}$}

Este trabalho está licenciado com uma Licença Creative Commons - Atribuição 4.0 Internacional. 